ISBN 978-602-17891-7-9

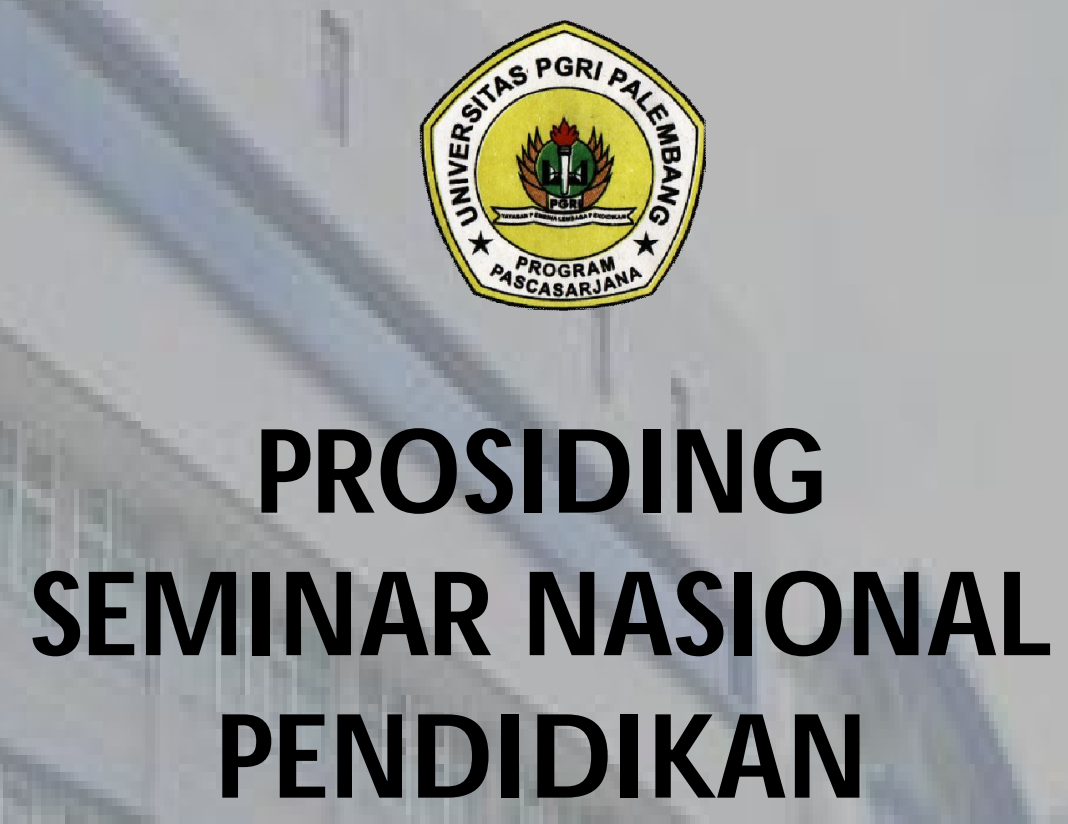

"M ewujudkan Sumber Daya M anusia yang Profesional dalam Kompetisi Global"

PROGRAM PASCASARJ ANA UNI VERSITAS PGRI PALEMBANG 2016 


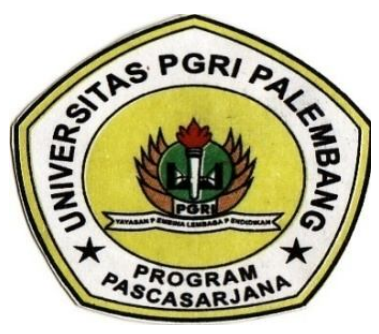

\section{PROSIDING \\ SEM INAR NASIONAL PENDIDIKAN \\ Program Pascasarjana Universitas PGRI Palembang \\ ISBN 978-602-17891-7-9}

\section{"MEW UJUDKAN SUM BER DAYA M ANUSIA YANG PRO FESIONAL DALAM KOM PETISI GLOBAL"}

Artikel-artikel dalam prosiding ini telah dipresentasikan pada Seminar Nasional Pendidikan pada tanggal 26 November 2016 di Aula Science Center Universitas PGRI Palembang

Tim Penyunting Artikel Seminar :

1. Prof. Dr. Hj. Ratu W ardarita, M .Pd.

2. Prof. Drs. Nangsari Ahmad, M.A., Ph.D.

3. Dr. Tahrun, M.Pd.

4. Dr. Hj. Nila Kesumawati, M.Si.

Sekretariat :

1. Febriansyah, S.E., M.M.

2. Rudi Hartono, S.Pd., M.Pd.

3. Chandra Kurniawan, S.E., M.Si.

4. Dian Lukmansyah.

Diterbitkan Oleh :

PROGRAM PASCASARJ ANA UNI VERSITAS PGRI PALEMBANG 2016 


\section{SAMBUTAN DIREKTUR PPS UNIVERSITAS PGRI PALEMBANG}

Assalammualaikum Wr. Wb

Salam sejahtera untuk kita semua.

Yang kami hormati Bapak Ketua YPLP-PT PGRI Sumatera Selatan, Bapak Rektor, Para Pembantu Rektor, Para Dekan, Para Kepala Biro, Para Kepala UPT beserta jajarannya. Yang kami muliakan para pemakalah baik pemakalah utama maupun pemakalah pendamping dan yang kami banggakan seluruh peserta seminar yang berbahagia. Pertama-tama marilah kita ucapkan rasa syukur kehadirat Tuhan yang Maha Esa, pemilik alam dan isinya, yang telah memberikan nikmat, terutama pada hari ini kita telah diberikan nikmat kesempatan dan kesehatan sehingga kita dapat dipertemukan pada forum yang terhormat ini untuk menghadiri dan mengikuti Seminar Nasional Pendidikan ke 18. Kegiatan seminar ini merupakan salah satu forum ilmiah yang telah diprogramkan secara rutin yang dilaksanakan setiap semester dengan mengangkat isuisu terkini.

Hadirin yang saya hormati, pada kesempatan kali ini saya ingin menyampaikan ucapan terima kasih kepada jajaran Program Pascasarjan (PPs) Universitas PGRI Palembang dan seluruh anggota panitia yang telah mampu mempersiapkan seminar nasional ini dengan baik. Selain itu, saya juga mengucapkan terima kasih kepada Bapak Rektor dan ketua YPLP-PT beserta jajarannya yang sangat kooperatif dalam membantu dan memfasilitasi seminar nasional ini. Penghargaan dan ucapan terima kasih juga disampaikan kepada para pembicara utama dari Universitas Negeri Jakarta Prof. Dr. Bedjo Sudjanto, M.Pd., dan dari Universitas Yogyakarta Prof. Dr. Suwardi Endaswara, M.Hum. Serta para pemakalah pendamping yang telah berkenan untuk berpartisipasi pada seminar nasional ini.

Hadirin yang berbahagia, Seminar Nasional Pendidikan ke 18 dengan tema "Mewujudkan Sumber Daya Manusia yang Profesional dalam Kompetensi Global" bertujuan untuk berbagi ide atau gagasan tentang bagaimana mewujudkan sumber daya manusia yang profesional dalam kompetensi global. Oleh karena itu, saya mengajak semuanya marilah kita ikuti seminar ini secara serius dan aktif sampai selesai. Selamat 
mengikuti seminar, mudah-mudahan kegiatan ini bermanfaat dan diridhoi oleh Tuhan Yang Maha Esa.

Akhir kata, saya selaku direktur PPs yang bertanggung jawab atas penyelenggaraan seminar nasional ini mohon maaf bila terdapat kekurangan dalam pelayanan dan penyelenggaraan kegiatan ini. Kritik dan saran yang membangun akan kami terima demi perbaikan kegiatan sejenis pada waktu yang akan datang.

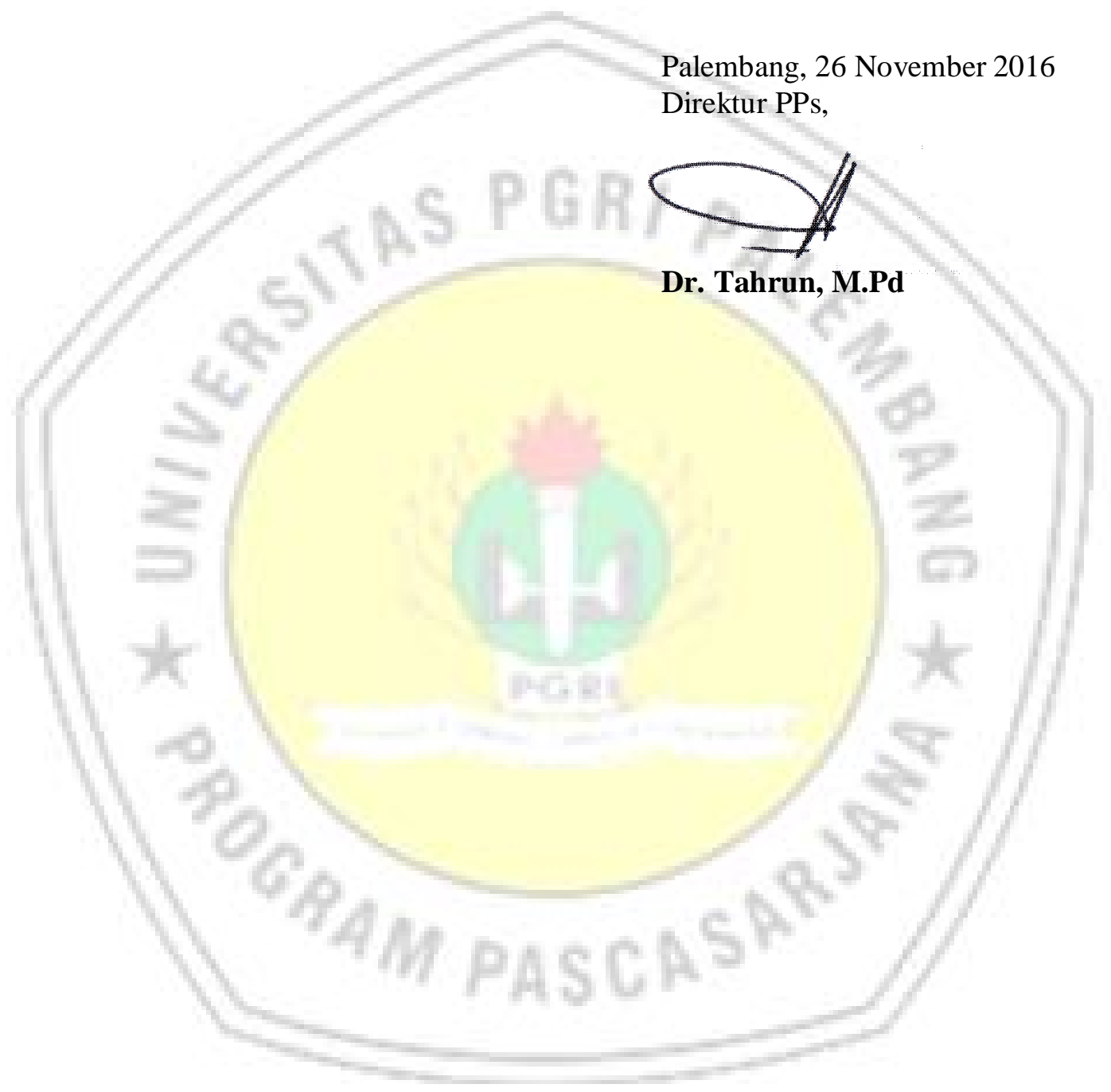




\section{KATA PENGANTAR}

Puji syukur kita ucapkan kehadirat Allah SWT karena atas berkat, rahmat dan karunia-Nya jua suatu karya berupa prosiding Seminar Nasional Pendidikan ke 18 ini dapat diselesaikan.

Adapun tujuan dari penerbitan prosiding ini adalah sebagai wahana informasi di bidang karya ilmiah khususnya di bidang pendidikan agar dapat disebarluaskan kepada para pencari informasi, peneliti, dosen, dan mahasiswa yang sedang menulis karya ilmiah. Di samping itu, karya ini adalah sebagai tempat berbagi pendapat yang pada gilirannya akan mendapat masukan dari para pembaca.Selain itu, prosiding ini juga akan menambah koleksi perpustakaan di ruang baca Program PascaSarjana (PPs).

Prosiding Seminar Nasional Pendidikan ke 18 ini adalah kumpulan karya ilmiah dari para penyaji makalah dalam seminar yang telah dilaksanakan oleh PPs Universitas PGRI Palembang pada tanggal 26 November 2016. Kami sadari sepenuhnya bahwa prosiding ini belum dapat memenuhi kepuasan para pembaca, namun setidaknya dapat membantu bagi pengguna informasi ilmiah di bidang pendidikan.

Akhir kata kami mengucapkan terima kasih kepada semua pihak yang telah membantu serta semua panitia pelaksana Seminar Nasional Pendidikan ke 18 ini. Kepada semua peserta dan pemakalah, komi mohon maaf jika ada kekurangan dalam pelayanan kami. Kepada Allah kami mohon ampun.

Palembang, 26 November 2016

Editor 


\section{DAFTAR ISI}

Cover Prosiding i

Balik Cover. ii

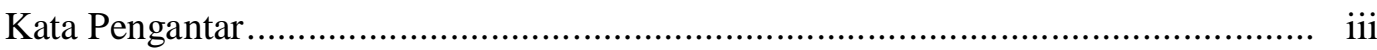

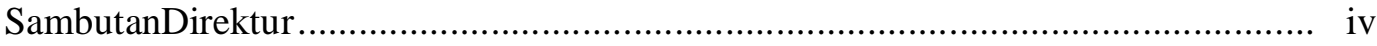

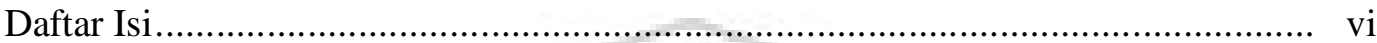

\begin{tabular}{|c|c|c|c|c|}
\hline \multicolumn{5}{|c|}{ MakalahUtama } \\
\hline No. & Judul & Nama & Instansi & Hal \\
\hline 1 & $\begin{array}{c}\text { KesadaranUntukBangkit, } \\
\text { MenghadapiPersaingan } \\
\text { Global: } \\
\text { SebuahKeniscayaan }\end{array}$ & BedjoSujanto & $\begin{array}{c}\text { Guru } \\
\text { BesarUniversitas } \\
\text { Negeri Jakarta }\end{array}$ & 1 \\
\hline & $\begin{array}{c}\text { SumberDayaProfesionalB } \\
\text { elajarSastra } \\
\text { di Era Globalisasi }\end{array}$ & Suwardi Endraswara & $\begin{array}{c}\text { Guru } \\
\text { BesarUniversitas } \\
\text { Yogyakarta }\end{array}$ & \\
\hline & $\sqrt{2+2}$ & 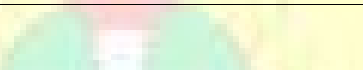 & $x^{2}=$ & \\
\hline \multicolumn{5}{|c|}{ Makalah Umum } \\
\hline No & Judul & Nama & Instansi & Hal \\
\hline 1 & $\begin{array}{c}\text { Mewujudkan Guru Yang } \\
\text { Profesional dan Upaya } \\
\text { Meningkatkan } \\
\text { Lembaga Pendidikan } \\
\text { Tenaga Kependidikan } \\
\text { (LPTK) }\end{array}$ & Ratu Wardarita & $\begin{array}{l}\text { Guru Besar PPs } \\
\text { Universitas PGRI } \\
\text { Palembang }\end{array}$ & 21 \\
\hline 2 & $\begin{array}{l}\text { PendidikanDalamArusPer } \\
\text { ubahan:MengkajiDuniaPe } \\
\text { ndidikan Indonesia }\end{array}$ & Nangsari Ahmad & $\begin{array}{c}\text { Guru Besar } \\
\text { UniversitasPGRI } \\
\text { Palembang }\end{array}$ & 32 \\
\hline 3 & Profesionalisme Guru & Mulyadi & $\begin{array}{l}\text { UniversitasPGRI } \\
\text { Palembang }\end{array}$ & 43 \\
\hline 4 & $\begin{array}{l}\text { Peran Kepemimpinan } \\
\text { Kepala Sekolah Dalam } \\
\text { Mengembangkan } \\
\text { Profesionalisme Guru }\end{array}$ & Herni Fitriani & $\begin{array}{l}\text { STKIP Nurul } \\
\text { Huda OKU } \\
\text { Timur }\end{array}$ & 50 \\
\hline
\end{tabular}




\begin{tabular}{|c|c|c|c|c|}
\hline 5 & $\begin{array}{l}\text { Strategi Pengembangan } \\
\text { Profesionalisme Guru } \\
\text { Bahasa Indonesia }\end{array}$ & Sugiarti & $\begin{array}{c}\text { STKIP Nurul } \\
\text { Huda OKU Timur }\end{array}$ & 61 \\
\hline 6 & $\begin{array}{c}\text { Model-Model } \\
\text { Pengembangan } \\
\text { Profesionalisme Guru }\end{array}$ & Nova Pratiwi & $\begin{array}{c}\text { Universitas } \\
\text { PGRIPalembang }\end{array}$ & 68 \\
\hline 7 & $\begin{array}{c}\text { Pendidikan Karakter } \\
\text { Pengembangan Nilai } \\
\text { Budaya Akademik dan } \\
\text { Etika Mahasiswa Dalam } \\
\text { Berperilaku di Lembaga } \\
\text { Pendidikan Tenaga } \\
\text { Kependidikan }\end{array}$ & & $\begin{array}{l}\text { Universitas PGRI } \\
\text { Palembang }\end{array}$ & 78 \\
\hline 8 & $\begin{array}{c}\text { Implikasi Konsep } \\
\text { Pemikiran Pendidikan } \\
\text { Islam Nurcholish Madjid } \\
\text { (Cak Nur) di Era Global }\end{array}$ & Sjech Dullah & $\begin{array}{r}\text { Universi } \\
\text { Palen }\end{array}$ & 93 \\
\hline 9 & $\begin{array}{l}\text { Relevansi Mata Kuliah } \\
\text { Pendidikan Pancasila } \\
\text { Dalam Era Globalisasi }\end{array}$ & Suryati & $\begin{array}{l}\text { Universitas PGRI } \\
\text { Palembang }\end{array}$ & 115 \\
\hline 10 & $\begin{array}{c}\text { Peningkatan Disposisi } \\
\text { Matematis dan } \\
\text { Kemampuan Pemahaman } \\
\text { Konsep Matematika Siswa } \\
\text { Dengan Problem Based } \\
\text { Learning di SMP Negeri } \\
16 \text { Palembang }\end{array}$ & $\begin{array}{c}\text { Eti } \\
\text { dan } \\
\text { Nila Kesumawati }\end{array}$ & $\begin{array}{l}\text { Mahasiswa dan } \\
\text { Dosen } \\
\text { UniversitasPGRI } \\
\text { Palembang }\end{array}$ & 124 \\
\hline 11 & Guru Profesional & Rudi Hartono & $\begin{array}{c}\text { UniversitasPGRI } \\
\text { Palembang }\end{array}$ & 136 \\
\hline 12 & $\begin{array}{c}\text { Pengaruh Pendekatan } \\
\text { Kontruktivisme Terhadap } \\
\text { Kemampuan Representasi } \\
\text { Matematis Siswa Kelas } \\
\text { VIII SMP Negeri } 32 \\
\text { Palembang }\end{array}$ & \begin{tabular}{|c|} 
Fadkholil \\
dan \\
Jumroh
\end{tabular} & $\begin{array}{l}\text { UniversitasPGRI } \\
\text { Palembang }\end{array}$ & 148 \\
\hline 13 & $\begin{array}{c}\text { Pembelajaran Menulis } \\
\text { Sastra Berbasis PAIKEM }\end{array}$ & Missriani & $\begin{array}{l}\text { Universitas PGRI } \\
\text { Palembang }\end{array}$ & 158 \\
\hline 14 & $\begin{array}{l}\text { Penerapan Model } \\
\text { Pembelajaran Cooperative } \\
\text { Learning untuk } \\
\text { Meningkatkan } \\
\text { Kemampuan Menulis Puisi }\end{array}$ & Sakdiah Wati & $\begin{array}{l}\text { UniversitasMuha } \\
\text { mmadiyah } \\
\text { Palembang }\end{array}$ & 174 \\
\hline
\end{tabular}




\begin{tabular}{|c|c|c|c|c|}
\hline 15 & $\begin{array}{c}\text { Pengaruh Motivasi dan } \\
\text { Kepuasan Kerja } \\
\text { Terhadap Kinerja Pegawai } \\
\text { (Studi Kasus Pada CV. } \\
\text { HAVRACO Jaya di } \\
\text { Palembang) }\end{array}$ & Yasir Arafat & $\begin{array}{c}\text { UniversitasPGRI } \\
\text { Palembang }\end{array}$ & 184 \\
\hline 16 & $\begin{array}{c}\text { Upaya Meningkatkan } \\
\text { Kemampuan Menulis Puisi } \\
\text { Siswa Kelas VIII SMPN } \\
43 \text { Palembang Melalui } \\
\text { Media Realia dan Teknik } \\
\text { Pemetaan Pikiran }\end{array}$ & Ida Rohana & $\begin{array}{c}\text { Guru SMPN } 43 \\
\text { Palembang }\end{array}$ & 199 \\
\hline 17 & $\begin{array}{l}\text { Peningkatan Kemampuan } \\
\text { Menulis Karangan Narasi } \\
\text { Melalui Strategi Peta } \\
\text { Konsep (Concept } \\
\text { Mapping) pada Siswa } \\
\text { Kelas X SMK Pelayaran } \\
\text { Sinar Bahari Palembang }\end{array}$ & $\begin{array}{l}\text { AchmadWahidydan } \\
\text { Yuli Hidaroyani }\end{array}$ & $\begin{array}{c}\text { UniversitasPGRI } \\
\text { Palembang } \\
\text { dan SMK } \\
\text { Pelayaran Sinar } \\
\text { Bahari Palembang }\end{array}$ & 211 \\
\hline 18 & $\begin{array}{l}\text { Analisis Hasil Uji Kinerja } \\
\text { Guru Ekonomi dan } \\
\text { Akuntansi Peserta } \\
\text { Pendidikan dan Latihan } \\
\text { Profesi Guru (PLPG) } 2016 \\
\text { Tahap II Pada Subrayon } \\
\text { 106 Universitas Sriwijaya }\end{array}$ & Zahruddin Hodsay & $\begin{array}{l}\text { Universitas PGRI } \\
\text { Palembang }\end{array}$ & 225 \\
\hline 19 & $\begin{array}{c}\text { Pengaruh Tingkat } \\
\text { Kepuasan Upah Terhadap } \\
\text { Kinerja Karyawan } \\
\text { di PTPN VII Distrik Cinta } \\
\text { Manis }\end{array}$ & $\begin{array}{l}\text { Chandra Kurniawan } \\
\text { dan } \\
\text { Fitriyanti }\end{array}$ & $\begin{array}{l}\text { Universitas } \\
\text { Palemb }\end{array}$ & 234 \\
\hline 20 & $\begin{array}{c}\text { Menumbuhkan } \\
\text { Keberanian Mahasiswa } \\
\text { Maju ke Depan } \\
\text { Mengerjakan Soal } \\
\text { Akuntansi Keuangan } \\
\text { Menengah 1 Melalui } \\
\text { Optimalisasi Satuan } \\
\text { Pembelajaran }\end{array}$ & Neta Dian Lestari & $\begin{array}{c}\text { Universitas PGRI } \\
\text { Palembang }\end{array}$ & 243 \\
\hline 21 & $\begin{array}{l}\text { Peningkatan Soft Skill dan } \\
\text { Hard Skill Mahasiswa } \\
\text { Berbasis Iptek Dalam } \\
\text { Proses Pembelajaran } \\
\text { Berdasarkan Bidang Studi }\end{array}$ & $\begin{array}{c}\text { Niko Citrawandi \& } \\
\text { Tenri Sau }\end{array}$ & $\begin{array}{c}\text { Universitas } \\
\text { Batanghari Jambi }\end{array}$ & 255 \\
\hline
\end{tabular}




\begin{tabular}{|c|c|c|c|c|}
\hline 22 & $\begin{array}{l}\text { Penerapan Model Picture } \\
\text { and Picture Terhadap } \\
\text { Hasil Pembelajaran dari } \\
\text { Aplikasi Hasil Penelitian } \\
\text { Herbisida Ekstrak Biji } \\
\text { Kelor } \\
\text { Terhadap Pertumbuhan } \\
\text { Gulma Eceng Gondok }\end{array}$ & $\begin{array}{l}\text { Saleh Hidayat, Susi } \\
\text { Dewiyeti, Fisri } \\
\text { Haryati }\end{array}$ & $\begin{array}{l}\text { Universitas } \\
\text { Muhammadiyah } \\
\text { Palembang }\end{array}$ & 261 \\
\hline 23 & $\begin{array}{l}\text { Promoting Local Culture } \\
\text { by Using 4-F Approach } \\
\text { in Elt Classroom }\end{array}$ & $\begin{array}{l}\text { Jenny Elvinna } \\
\text { Manurung }\end{array}$ & $\begin{array}{l}\text { Universitas } \\
\text { Tridinanti } \\
\text { Palembang }\end{array}$ & 271 \\
\hline 24 & $\begin{array}{l}\text { The Influnces of Using } \\
\text { Pictures Series in } \\
\text { Student's Writing } \\
\text { Composition to the Eighth } \\
\text { Grade Students of SMP } \\
\text { PGRI1 Palembang }\end{array}$ & Etty Pratiwi & Uni & 280 \\
\hline 25 & $\begin{array}{l}\text { The Effects of the } \\
\text { Adoptions of } \\
\text { Communicative Language } \\
\text { Teaching Approach and } \\
\text { Grammar Translation } \\
\text { Method on the } 1^{\text {st }} \text { Year } \\
\text { Students' Speaking } \\
\text { Abilities of FKIP UBL }\end{array}$ & Baginda Simaibang & $\begin{array}{l}\text { Universitas PGRI } \\
\text { Palembang }\end{array}$ & 293 \\
\hline 26 & $\begin{array}{l}\text { Professional Development } \\
\text { Programs for Teachers }\end{array}$ & Sry Mulya Kurniati & $\begin{array}{l}\text { University of } \\
\text { IGM Palembang } \\
\text { \& SMK N. } 6 \\
\text { Palembang }\end{array}$ & 306 \\
\hline 27 & $\begin{array}{l}\text { Using Classdojo as a } \\
\text { Technology-Enabled } \\
\text { Feedback to Promote } \\
\text { Students' Positive } \\
\text { Behaviors }\end{array}$ & Diana Luspa & $\begin{array}{l}\text { University of } \\
\text { PGRI Palembang }\end{array}$ & 313 \\
\hline 28 & $\begin{array}{l}\text { Kawasan Pantai Kuno } \\
\text { Desa Sako Rambutan } \\
\text { Sebagai Sumber } \\
\text { Pembelajaran Sejarah }\end{array}$ & $\begin{array}{l}\text { Ahmad Zamhari } \\
\text { dan } \\
\text { Refiko Apriansyah }\end{array}$ & $\begin{array}{c}\text { Universitas PGRI } \\
\text { Palembang }\end{array}$ & 317 \\
\hline 29 & $\begin{array}{c}\text { Dialektika Kebudayaan } \\
\text { Iliran dan Uluan Dalam } \\
\text { Seni Aksitektur Rumah } \\
\text { Suku Ogan Sebagai } \\
\text { Sumber Pembelajaran } \\
\end{array}$ & $\begin{array}{l}\text { Muhamad Idris } \\
\text { dan } \\
\text { Jeki Sepriady }\end{array}$ & $\begin{array}{c}\text { UniversitasPGRI } \\
\text { Palembang }\end{array}$ & 326 \\
\hline
\end{tabular}




\begin{tabular}{|c|c|c|c|c|}
\hline & Sejarah & & & \\
\hline 30 & $\begin{array}{c}\text { Pemukiman Kuno di } \\
\text { Pesisir Pantai Timur } \\
\text { Sumatera Selatan Sebagai } \\
\text { Sumber Pembelajaran } \\
\text { Sejarah }\end{array}$ & $\begin{array}{c}\text { Sukardidan } \\
\text { Brian Apriadi }\end{array}$ & $\begin{array}{c}\text { UniversitasPGRI } \\
\text { Palembang }\end{array}$ & 335 \\
\hline 31 & $\begin{array}{c}\text { Alumni Sebagai Strategi } \\
\text { Pemasaran di Perguruan } \\
\text { Tinggi }\end{array}$ & Arif Ardiansyah & $\begin{array}{c}\text { UniversitasPGRI } \\
\text { Palembang }\end{array}$ & 345 \\
\hline 32 & $\begin{array}{l}\text { Mendidik Ala Nabi } \\
\text { Muhammad SAW. }\end{array}$ & Ahmad Sulaiman & $\begin{array}{l}\text { UIN Raden Fatah } \\
\text { Palembang }\end{array}$ & 351 \\
\hline 33 & $\begin{array}{c}\text { Strategi Pendidik } \\
\text { Profesional Dalam } \\
\text { Meningkatkan Mutu } \\
\text { Peserta Didik Dalam } \\
\text { Menghadapi Kompetisi } \\
\text { Global }\end{array}$ & Allen Marga Retta & rsitasPGRI & 360 \\
\hline 34 & $\begin{array}{c}\text { Menjadi Guru } \\
\text { Profesional di Era } \\
\text { Globalisasi } \\
\end{array}$ & Novita Sari & $\begin{array}{l}\text { UniversitasPGRI } \\
\text { Palembang }\end{array}$ & 367 \\
\hline 35 & $\begin{array}{c}\text { Aplikasi Edmodo Sebagai } \\
\text { Media Pembelajaran E- } \\
\text { Learning }\end{array}$ & Putri Fitriasari & $\begin{array}{l}\text { UniversitasPGRI } \\
\text { Palembang }\end{array}$ & 377 \\
\hline 36 & $\begin{array}{c}\text { Penyusunan Laporan } \\
\text { Keuangan Bagi Pengelola } \\
\text { Koperasi Syariah Musi } \\
\text { Sejahtera dan CV Nurul } \\
\text { Abadi Palembang }\end{array}$ & $\begin{array}{c}\text { Zahruddin, Neta Dian } \\
\text { Lestari, Bram Sista } \\
\text { Apriyanto, Ande } \\
\text { Sugama }\end{array}$ & $\begin{array}{l}\text { UniversitasPGRI } \\
\text { Palembang }\end{array}$ & 385 \\
\hline 37 & & Tahrun & $\begin{array}{c}\text { UniversitasPGRI } \\
\text { Palembang }\end{array}$ & 398 \\
\hline
\end{tabular}

\begin{tabular}{|c|c|c|c|c|}
\hline \multicolumn{5}{|c|}{ Makalah Manajemen Pendidikan } \\
\hline No. & Judul & Nama & Instansi & Hal \\
\hline 1 & $\begin{array}{c}\text { Pengembangan } \\
\text { Profesionalisme Guru } \\
\text { DalamMengembangkan } \\
\text { Potensi Peserta Didik } \\
\text { Melalui Pendidikan Global }\end{array}$ & Septi Andriani & $\begin{array}{l}\text { Bimbingan } \\
\text { Belajar Teknos } \\
\text { Genius, } \\
\text { Palembang }\end{array}$ & 408 \\
\hline 2 & $\begin{array}{l}\text { Pemanfaatan Aplikasi } \\
\text { Sagusanov Dalam } \\
\text { Pembelajaran Berbasis } \\
\text { Android Pada Mata } \\
\text { Pelajaran IPS }\end{array}$ & Dwi Oktaviani & $\begin{array}{l}\text { SMP Negeri } 9 \\
\text { Prabumulih }\end{array}$ & 421 \\
\hline
\end{tabular}




\begin{tabular}{|c|c|c|c|c|}
\hline 3 & $\begin{array}{c}\text { Peran Guru Dalam } \\
\text { Pendidikan Karakter untuk } \\
\text { Meningkatkan Daya Saing } \\
\text { Pada Era Global Bagi } \\
\text { Siswa di Daerah }\end{array}$ & $\begin{array}{l}\text { FatmiAndiRizkiPrata } \\
\mathrm{mi}\end{array}$ & $\begin{array}{l}\text { SMA Negeri } 1 \\
\text { SumberMargaTel } \\
\text { ang, Banyuasin }\end{array}$ & 429 \\
\hline 4 & $\begin{array}{c}\text { Profesionalisme Guru } \\
\text { Dalam Meningkatkan } \\
\text { Mutu Pendidikan } \\
\text { di Sekolah Dasar pada Era } \\
\text { Globalisasi }\end{array}$ & Mita Sukma Fitrian & $\begin{array}{c}\text { UniversitasPGRI } \\
\text { Palembang }\end{array}$ & 437 \\
\hline 5 & $\begin{array}{c}\text { Peningkatan Self Efficacy } \\
\text { dan Kemampuan } \\
\text { Representasi Matematis } \\
\text { Siswa dengan Problem } \\
\text { Based Learning Di SMP } \\
\text { Negeri } 16 \text { Palembang }\end{array}$ & $\begin{array}{c}\text { Ria Linci Ovriska dan } \\
\text { Ety Septiati }\end{array}$ & $\begin{array}{c}\text { UniversitasPGRI } \\
\text { Palembang }\end{array}$ & 449 \\
\hline 6 & $\begin{array}{c}\text { Penerapan Kepemimpinan } \\
\text { Transformasional } \\
\text { Dalam Supervisi } \\
\text { Pendidikan } \\
\end{array}$ & Heriana Hartiwi & $\begin{array}{l}\text { SD Negeri } 165 \\
\text { Palembang }\end{array}$ & 459 \\
\hline 7 & $\begin{array}{c}\text { Model } \\
\text { PembelajaranFlipper } \\
\text { ClassroomMenujuPendidi } \\
\text { kan Global }\end{array}$ & Hamdani & $\begin{array}{c}\text { SMANegeri } 1 \\
\text { Banyuasin Ii, } \\
\text { Kabupaten } \\
\text { Banyuasin }\end{array}$ & 470 \\
\hline 8 & $\begin{array}{c}\text { AlihFungsi Guru } \\
\text { SMKDalamPeningkatanPe } \\
\text { ngembanganProfesionalis } \\
\text { me }\end{array}$ & Suryadi & $\begin{array}{l}\text { SMK YP Gajah } \\
\text { Mada Palembang }\end{array}$ & 481 \\
\hline 9 & $\begin{array}{l}\text { Profesionalisme Guru } \\
\text { Daerah Terpencil }\end{array}$ & Zahrasade & $\begin{array}{c}\text { SDNegeri } 30 \\
\text { Banyuasin I }\end{array}$ & 490 \\
\hline 10 & $\begin{array}{c}\text { Pengaruh Kepemimpinan } \\
\text { Kepala Sekolah Terhadap } \\
\text { Kinerja Guru }\end{array}$ & Nina Suzzannah & $\begin{array}{l}\text { SMP Negeri } 29 \\
\text { Palembang }\end{array}$ & 498 \\
\hline 11 & $\begin{array}{l}\text { Kepemimpinan Efektif } \\
\text { Kepala Sekolah Dalam } \\
\text { Mengelola } \\
\text { Sekolah Alam Bagi Siswa } \\
\text { Miskin dan Putus Sekolah }\end{array}$ & Herdayati & $\begin{array}{l}\text { StikesMuhammad } \\
\text { iyah Palembang }\end{array}$ & 510 \\
\hline 12 & $\begin{array}{c}\text { Menanamkan Nilai- nilai } \\
\text { dari PembelajaranGuru TK } \\
\text { Negeri Pembina } 1 \\
\text { Palembang }\end{array}$ & Rozalena & $\begin{array}{l}\text { TKNegeri } \\
\text { Pembina I } \\
\text { Palembang }\end{array}$ & 522 \\
\hline
\end{tabular}




\begin{tabular}{|c|c|c|c|c|}
\hline 13 & $\begin{array}{c}\text { PeningkatanSoft Skill Dan } \\
\text { Hard } \\
\text { SkillMahasiswaBerbasis } \\
\text { IPTEKDalam Proses } \\
\text { PembelajaranBerdasarkan } \\
\text { BidangStudi }\end{array}$ & $\begin{array}{c}\text { TenriSau Dan Niko } \\
\text { Citrawandi }\end{array}$ & $\begin{array}{l}\text { Universitas } \\
\text { Batanghari }\end{array}$ & 534 \\
\hline 14 & $\begin{array}{l}\text { Pemanfaatan Teknologi } \\
\text { InformasiDalam } \\
\text { Pelayanan Bimbingan } \\
\text { Konseling }\end{array}$ & Helma Nur & $\begin{array}{l}\text { SMA Negeri } 5 \\
\text { Palembang }\end{array}$ & 540 \\
\hline 15 & $\begin{array}{l}\text { Pengembangan Sumber } \\
\text { Daya Manusia Sebagai } \\
\text { Salah Satu Faktor Penentu } \\
\text { Dalam Meningkatkan } \\
\text { Mutu Pendidikan }\end{array}$ & $\begin{array}{l}\text { Reza Aulia Akbar Dan } \\
\text { Tobari }\end{array}$ & $\begin{array}{l}\text { UniversitasPGRI } \\
\text { Palembang }\end{array}$ & 550 \\
\hline 16 & $\begin{array}{c}\text { Pengaruh Kepemimpinan } \\
\text { Terhadap Kinerja Pegawai } \\
\text { Negeri Sipil di Kantor } \\
\text { Kecamatan Seberang Ulu } \\
\text { II Palembang }\end{array}$ & EviRobianti & $\begin{array}{c}\text { DinasPendidikan } \\
\text { Pemuda Dan } \\
\text { Olahraga } \\
\text { Palembang }\end{array}$ & 560 \\
\hline 17 & $\begin{array}{l}\text { Peran Kepemimpinan } \\
\text { Kepala Sekolah Terhadap } \\
\text { Peningkatan Kinerja Guru }\end{array}$ & $\begin{array}{c}\text { Jimmi Yuliandridan } \\
\text { Muhammad } \\
\text { Kristiawan }\end{array}$ & $\begin{array}{c}\text { Guru Sekolah } \\
\text { Dasar Negeri } 12 \\
\text { Rambutan } \\
\text { Banyuasindan } \\
\text { Dosen } \\
\text { UniversitasPGRI } \\
\text { Palembang } \\
\end{array}$ & 570 \\
\hline 18 & $\begin{array}{l}\text { Peran Kepemimpinan } \\
\text { Kepala 19Sekolah Dalam } \\
\text { Membentuk Sikap Guru } \\
\text { Dalam Pembelajaran }\end{array}$ & Ria Agustin & $\begin{array}{r}\text { SMPNe } \\
\text { Palem }\end{array}$ & 578 \\
\hline 19 & $\begin{array}{c}\text { Kemampuan Kepala } \\
\text { Sekolah Dalam Membina } \\
\text { dan Melaksanakan } \\
\text { Supervisi untuk } \\
\text { Menunjang Profesinalisme } \\
\text { Guru di MTs Negeri 1 } \\
\text { Palembang }\end{array}$ & Herlina & $\begin{array}{c}\text { Madrasah } \\
\text { TsanawiyahNeger } \\
\text { i1 Palembang }\end{array}$ & 589 \\
\hline 20 & $\begin{array}{c}\text { Pemberdayaan Guru } \\
\text { SebagaiLangkahPeningkat } \\
\text { anProfesionalisme } \\
\text { olehKepalaSekolah }\end{array}$ & MellyDamayanti & $\begin{array}{c}\text { SMPNegeri } 37 \\
\text { Palembang }\end{array}$ & 599 \\
\hline
\end{tabular}




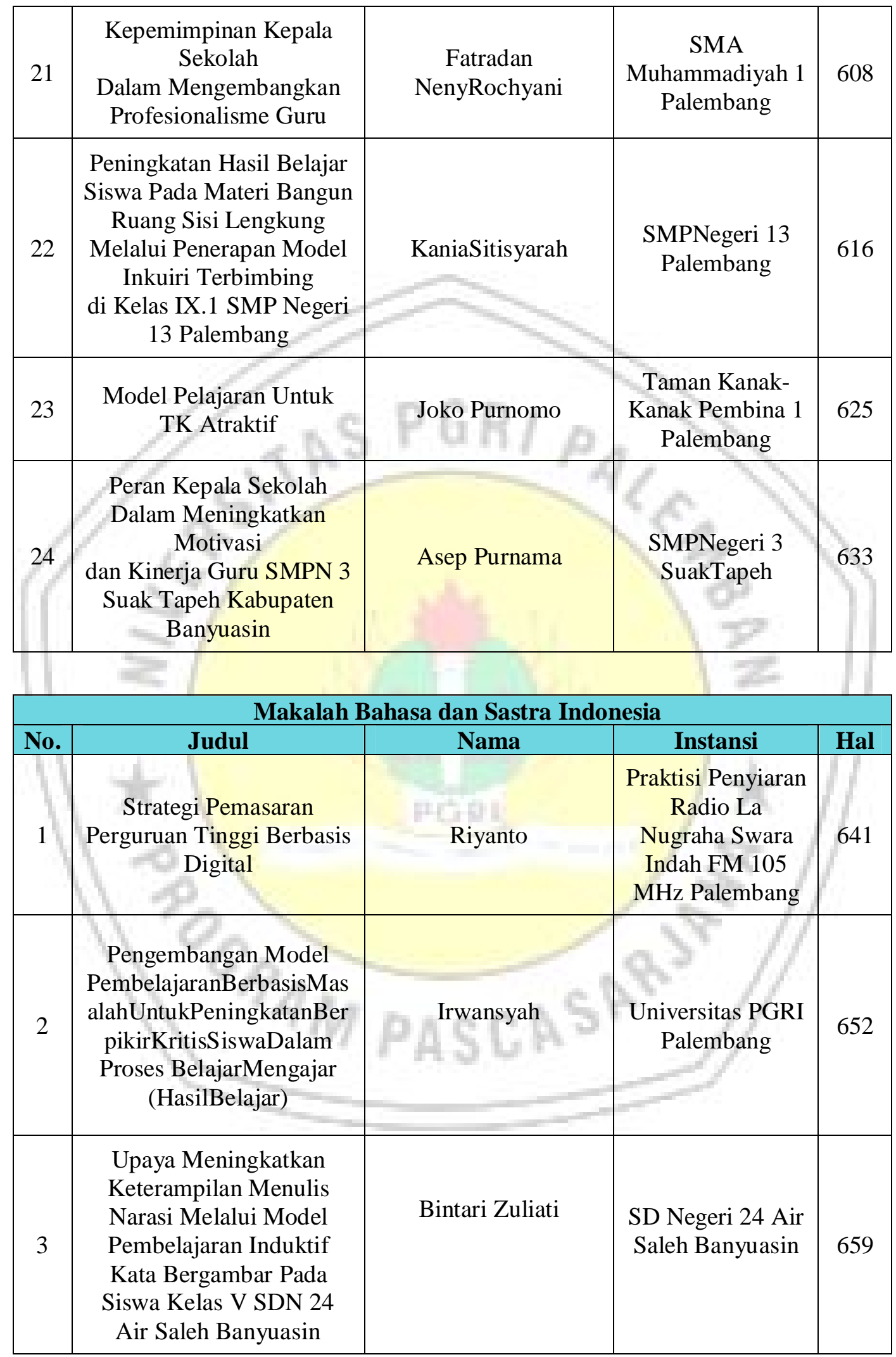




\begin{tabular}{|c|c|c|c|c|}
\hline 4 & $\begin{array}{c}\text { Peningkatan Kemampuan } \\
\text { Membedakan Paragraf } \\
\text { Induktif dan Deduktif } \\
\text { Dalam Wacana Melalui } \\
\text { Model Kooperatif Tipe } \\
\text { Stad } \\
\text { Siswa Kelas VII 2 SMP } \\
\text { Negeri } 1 \text { Tanjung Lubuk } \\
\text { OKI }\end{array}$ & CikSaleha & $\begin{array}{l}\text { SMP Negeri } 1 \\
\text { TanjungLubuk } \\
\text { OKI }\end{array}$ & 668 \\
\hline 5 & $\begin{array}{c}\text { PengaruhTunjanganProfesi } \\
\text { Guru } \\
\text { TerhadapPeningkatanProfe } \\
\text { sionalisme Guru Melalui } \\
\text { Program Sertifikasi }\end{array}$ & $\begin{array}{l}\text { Deliwati } \\
\text { (17) }\end{array}$ & $\begin{array}{c}\text { UPTD Pendidikan } \\
\text { dan Kebudayaan } \\
\text { Kecamatan } \\
\text { Lembak dan } \\
\text { Kelekar, } \\
\text { Muaraenim } \\
\end{array}$ & 678 \\
\hline 6 & $\begin{array}{l}\text { Kompetensi dan Strategi } \\
\text { Pengembangan Karakter } \\
\text { Profesionalisme Guru } \\
\text { Dalam Pembelajaran } \\
\text { Bahasa }\end{array}$ & Hendarlina & Teluk C & 686 \\
\hline 7 & $\begin{array}{c}\text { Perlunya Inovasi } \\
\text { Kurikulum, Inovasi } \\
\text { Pembelajaran, dan Inovasi } \\
\text { Manajemen Kelas Dalam } \\
\text { Bersastra Ria }\end{array}$ & Melo Kasmarani & SMK Telenika & 695 \\
\hline 8 & $\begin{array}{l}\text { Peran Guru Dalam } \\
\text { Keterampilan Menulis } \\
\text { Puisi } \\
\text { Dengan Menggunakan } \\
\text { Media Audio Visual }\end{array}$ & Neli Yulianti & $\begin{array}{l}\text { Universitas PGRI } \\
\text { Palembang }\end{array}$ & 704 \\
\hline 9 & $\begin{array}{c}\text { Kompetensi } \\
\text { Profesionalisme Guru } \\
\text { Bahasa Indonesia } \\
\text { Dalam Pengajaran Sastra }\end{array}$ & Rina Pebriana & $\begin{array}{l}\text { SDIT Nurul Iman } \\
\text { Palembang }\end{array}$ & 712 \\
\hline 10 & $\begin{array}{c}\text { Pembinaan Profesional } \\
\text { Guru Dalam } \\
\text { Mengefektifkan } \\
\text { Pembelajaran } \\
\text { Melalui Supervisi Kelas }\end{array}$ & Rusmianah & $\begin{array}{c}\text { SMP Negeri I } \\
\text { Teluk Gelam OKI }\end{array}$ & 721 \\
\hline
\end{tabular}




\begin{tabular}{|c|c|c|c|c|}
\hline 11 & $\begin{array}{c}\text { Mewujudkan } \\
\text { Profesionalisme Guru } \\
\text { Dalam Pembelajaran } \\
\text { Bahasa Indonesia Melalui } \\
\text { PTK }\end{array}$ & Tina & $\begin{array}{c}\text { SMA Negeri I } \\
\text { GunungMegang }\end{array}$ & 730 \\
\hline 12 & $\begin{array}{l}\text { Peningkatan Kemampuan } \\
\text { Teknologi Dalam } \\
\text { Pengembangan } \\
\text { Profesionalisme Guru } \\
\text { Bahasa Melalui Problem } \\
\text { Solving }\end{array}$ & Yuliwati & $\begin{array}{l}\text { M.I Hijriyah } 6 \\
\text { Palembang }\end{array}$ & 738 \\
\hline 13 & $\begin{array}{c}\text { Peningkatan } \\
\text { Profesionalisme Guru } \\
\text { Melalui Penerapan Strategi } \\
\text { Metakognitif Dalam } \\
\text { Pembelajaran Bahasa di } \\
\text { Sekolah Dasar }\end{array}$ & ZumrotusSa'diyah & & 749 \\
\hline 14 & $\begin{array}{c}\text { Model } \\
\text { PembelajaranBahasadanSa } \\
\text { stra } \\
\text { di SDNegeri } 24 \text { Air Saleh } \\
\text { KabupatenBanyuasin }\end{array}$ & Wartik & $\begin{array}{l}\text { SD Negeri } 24 \text { Air } \\
\text { Saleh Banyuasin }\end{array}$ & 759 \\
\hline 15 & $\begin{array}{c}\text { MenstimulusPesertaDidik } \\
\text { BertanyaDalamPendekatan } \\
\text { Saintifik }\end{array}$ & Nyimas Laili Yulita & $\begin{array}{l}\text { SMP Negeri } 11 \\
\text { Palembang }\end{array}$ & 767 \\
\hline 16 & $\begin{array}{c}\text { Peningkatan Kemampuan } \\
\text { Membaca Melalui } \\
\text { Model Pengalaman } \\
\text { Berbahasa Terkonsentrasi }\end{array}$ & Syaiful Anam & $\begin{array}{l}\text { MTs. Nurul Huda } \\
\text { Sukaraja OKU } \\
\text { Timur }\end{array}$ & 775 \\
\hline 17 & $\begin{array}{l}\text { HubunganSemantisAntarkl } \\
\text { ausaDalamKalimatMajem } \\
\text { uk Yang TerdapatDalam } \\
\text { "Tribun Corner" } \\
\text { SuratKabarTribunSumselB } \\
\text { ulan April } 2015\end{array}$ & 7. Yerdawani & $\begin{array}{l}\text { SD Negeri } 4 \\
\text { Pedamaran }\end{array}$ & 783 \\
\hline 18 & $\begin{array}{l}\text { Kesenjangan Dalam } \\
\text { Profesionalisme Guru }\end{array}$ & Yuniwiarti & $\begin{array}{l}\text { SMP Negeri } 34 \\
\text { Palembang }\end{array}$ & 791 \\
\hline 19 & $\begin{array}{c}\text { Peningkatan Kemampuan } \\
\text { Dalam Berbicara Siswa } \\
\text { SD Palembang } \\
\text { Melalui Teknik Pemodelan }\end{array}$ & Nursana & $\begin{array}{l}\text { Universitas PGRI } \\
\text { Palembang }\end{array}$ & 799 \\
\hline
\end{tabular}




\begin{tabular}{|c|c|c|c|c|}
\hline 20 & $\begin{array}{c}\text { Faktor-FaktorPenghambat } \\
\text { Guru Pembelajar }\end{array}$ & Septi Reni & $\begin{array}{l}\text { SMA Negeri } 21 \\
\text { Palembang }\end{array}$ & 811 \\
\hline 21 & $\begin{array}{c}\text { Sikap Bahasa dan } \\
\text { Pemilihan Bahasa Siswa } \\
\text { Terhadap Bahasa } \\
\text { Indonesia }\end{array}$ & Leli & $\begin{array}{l}\text { SMP Abadi } 2 \\
\text { Petaling }\end{array}$ & 817 \\
\hline 22 & $\begin{array}{c}\text { Pentingnya Minat Baca } \\
\text { Dalam Meningkatkan } \\
\text { Keterampilan Menulis } \\
\text { Siswa }\end{array}$ & & $\begin{array}{l}\text { SMP N } 30 \\
\text { Palembang }\end{array}$ & 825 \\
\hline 23 & $\begin{array}{l}\text { Uji Kompetensi Guru } \\
\text { Dalam Peningkatan } \\
\text { Profesionalisme dan } \\
\text { Kualitas Pendidikan }\end{array}$ & Siska Yulia Sari & $\begin{array}{c}\text { Universitas PGRI } \\
\text { Palembang }\end{array}$ & 833 \\
\hline \multicolumn{5}{|c|}{ Makalah Bahasa Inggris } \\
\hline No. & Judul & Nama & Instansi & Hal \\
\hline 1 & $\begin{array}{l}\text { Classroom Management } \\
\text { for Teacher in English } \\
\text { Learning Process }\end{array}$ & Amiruddin & $\begin{array}{c}\text { University of } \\
\text { PGRI Palembang }\end{array}$ & 842 \\
\hline 2 & $\begin{array}{l}\text { Improving Teaching } \\
\text { Learning Strategies to } \\
\text { Increase Teachers' Skill in } \\
\text { Global Era }\end{array}$ & Arief Rahman Hakim & $\begin{array}{c}\text { University of } \\
\text { PGRI Palembang }\end{array}$ & 849 \\
\hline 3 & $\begin{array}{l}\text { The Implication of First } \\
\text { Aid in English System } \\
\text { (FAIES) And } \\
\text { Drilling Technique Used in } \\
\text { Teaching Vocabulary }\end{array}$ & Ayu Novitasari & PGRI Palen & 858 \\
\hline 4 & $\begin{array}{l}\text { Internet Technologies As } \\
\text { Cognitive Tools for } \\
\text { Student-Centered Learning }\end{array}$ & Dana Listiyanti & $\begin{array}{c}\text { University of } \\
\text { PGRI Palembang }\end{array}$ & 866 \\
\hline 5 & $\begin{array}{l}\text { Challenges for The } \\
\text { Teacher in The Era of } \\
\text { Globalization }\end{array}$ & Eva Rahma Sari & $\begin{array}{c}\text { University of } \\
\text { PGRI Palembang }\end{array}$ & 875 \\
\hline 6 & $\begin{array}{l}\text { Using Online Social } \\
\text { Networking as Media } \\
\text { Teaching and Learning } \\
\text { For English Teacher }\end{array}$ & Fenny Octari Zega & $\begin{array}{c}\text { University of } \\
\text { PGRI Palembang }\end{array}$ & 885 \\
\hline 7 & Improving Human & Fenny Tridiarmi & University of & 894 \\
\hline
\end{tabular}




\begin{tabular}{|c|c|c|c|c|}
\hline & $\begin{array}{l}\text { Resource Through } \\
\text { Character Building }\end{array}$ & & PGRI Palembang & \\
\hline 8 & $\begin{array}{l}\text { The Strategies of English } \\
\text { Teacher in Developing } \\
\text { Students' Writing } \\
\text { Ability in Global Era }\end{array}$ & Helga & $\begin{array}{c}\text { University of } \\
\text { PGRI Palembang }\end{array}$ & 901 \\
\hline 9 & $\begin{array}{c}\text { Improving The Teachers' } \\
\text { Skill in Teaching Young } \\
\text { Learnersin Globalization } \\
\text { Era }\end{array}$ & Iskandar & $\begin{array}{c}\text { University of } \\
\text { PGRI Palembang }\end{array}$ & 908 \\
\hline 10 & $\begin{array}{l}\text { Classroom Interaction } \\
\text { Betweenteacher Talk and } \\
\text { Student Talk in English for } \\
\text { Young Learners (EYL) in } \\
\text { Global Era }\end{array}$ & Jeri Apriadi & $\begin{array}{l}\text { ity of } \\
\text { embang }\end{array}$ & 916 \\
\hline 11 & $\begin{array}{c}\text { Students' Learning } \\
\text { Motivation in Speaking } \\
\text { English (EFL) } \\
\text { as Preparation to Face Free } \\
\text { Trade } \\
\end{array}$ & Leni Triana & $\begin{array}{c}\text { University of } \\
\text { PGRI Palembang }\end{array}$ & 923 \\
\hline 12 & $\begin{array}{l}\text { Improving Teacher's Skill } \\
\text { in Global Era }\end{array}$ & Nazipah & $\begin{array}{c}\text { University of } \\
\text { PGRI Palembang }\end{array}$ & 930 \\
\hline 13 & $\begin{array}{l}\text { The Difficulties in } \\
\text { Analysis of Poetry }\end{array}$ & Nita Ria & $\begin{array}{l}\text { Universitas } \\
\text { Tridinanti } \\
\text { Palembang }\end{array}$ & 941 \\
\hline 14 & $\begin{array}{l}\text { The Effective Ways for } \\
\text { Students in Speaking } \\
\text { Actively in Facing The } \\
\text { Global Challenges }\end{array}$ & Oktrianti Diani & $\begin{array}{l}\text { University of } \\
\text { PGRI Palembang }\end{array}$ & 951 \\
\hline 15 & $\begin{array}{l}\text { Audio-Lingual Method: } \\
\text { Its Effect On Intermidiate } \\
\text { Students' Listening } \\
\text { Comprehension }\end{array}$ & Qorie Pratiwi & $\begin{array}{l}\text { University of } \\
\text { PGRI Palembang }\end{array}$ & 958 \\
\hline 16 & $\begin{array}{l}\text { Challenges Faced by } \\
\text { Teachers and Learners of } \\
\text { English Teaching and } \\
\text { Learning English as a } \\
\text { Second Language }\end{array}$ & RahmitaDwi Lestari & $\begin{array}{c}\text { University of } \\
\text { PGRI Palembang }\end{array}$ & 967 \\
\hline 17 & $\begin{array}{c}\text { Building Professionalism } \\
\text { of Teacher in Dealing With } \\
\text { Global Era }\end{array}$ & Rini Oktarisa & $\begin{array}{c}\text { University of } \\
\text { PGRI Palembang }\end{array}$ & 974 \\
\hline
\end{tabular}




\begin{tabular}{|c|c|c|c|c|}
\hline 18 & $\begin{array}{c}\text { Realizing of Professional } \\
\text { Teacher in Building a } \\
\text { Quality and Competitive } \\
\text { Education }\end{array}$ & Wira Lestari & $\begin{array}{c}\text { University of } \\
\text { PGRI Palembang }\end{array}$ & 982 \\
\hline
\end{tabular}

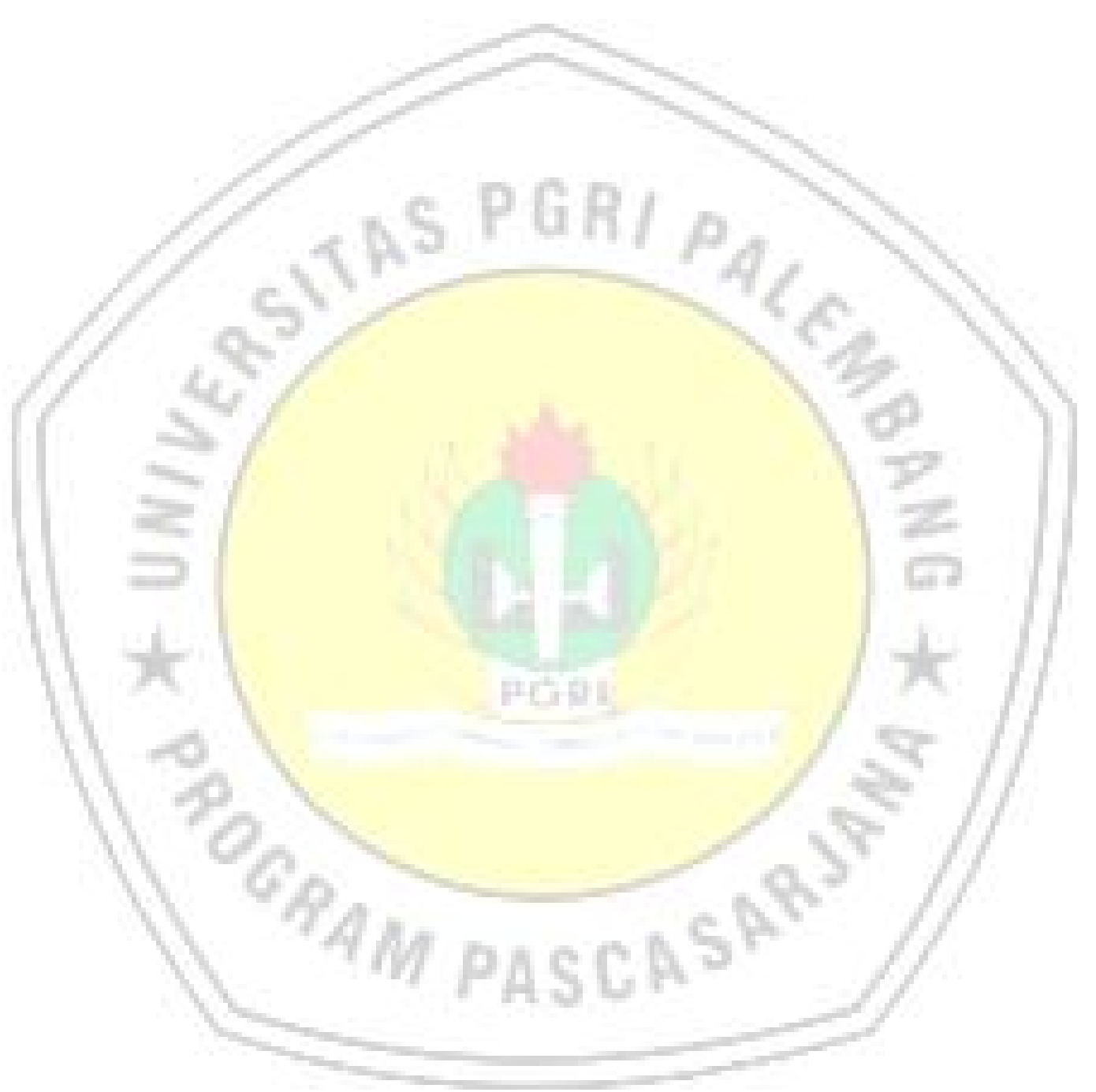




\title{
PERAN KEPEMIMPINAN KEPALA SEKOLAH TERHADAP PENINGKATAN KINERJA GURU
}

\author{
Jimmi Yuliandri dan Muhammad Kristiawan \\ Sekolah Dasar Negeri 12 Rambutan Banyuasin \\ Universitas PGRI Palembang \\ e-mail: muhammad.kristiawan@yahoo.co.id
}

\begin{abstract}
This study was conducted in order to reveal the role of principal leadership on improving teacher's performance. The data were obtained through interview, documentation and observation. An increase of teachers' performance may also improve the quality of education and quality of teaching. To achieve eligibility standards and good performance, the school needs to be headed by a Principal whom qualified with extensive knowledge about the Leadership. A school principal is responsible for the educational organization, school administration, utilization and maintenance of facilities and infrastructure, and coaching educational personnel. No matter how perfect the teaching facility, otherwise when the headmaster as executor is unable to perform his duties as an educational leader, then the success of education in schools would be difficult to achieve.
\end{abstract}

\section{Keywords: Leadership, Principal, Teachers' Performance}

\section{Pendahuluan}

Penelitian ini berawal dari permasalahan di berbagai sekolah berkaitan dengan kinerja guru. Perkembangan ilmu pengetahuan dan teknologi dalam era globalisasi menuntut tenaga kerja yang terampil dan bermutu. Tanpa terkecuali, pada suatu lembaga pendidikan yakni sekolah menuntut mutu dan profesional kerja dari guru-gurunya agar dapat menghasilkan mutu pendidikan yang baik pula pada sekolah tersebut.

Sekolah merupakan satuan pendidikan yang menyelenggarakan proses belajar mengajar mempunyai fungsi dan tujuan sebagaimana yang dimuat dalam Undang-Undang Nomor 20 tahun 2003 pasal 3, tentang sistem pendidikan nasional yaitu, "mengembangkan kemampuan dan membentuk watak serta peradaban bangsa yang bermartabat dalam rangka mencerdaskan kehidupan bangsa, bertujuan untuk mengembangkan potensi peserta didik agar menjadi manusia yang beriman dan bertakwa kepada Tuhan Yang Maha Esa, berakhlak mulia, sehat, berilmu, cakap, kreatif, mandiri, dan menjadi warga negara yang demokratis serta bertanggung jawab". Namun pada kenyataannya, masih banyak sekolah yang belum memahami maksud sesungguhnya dari isi undang-undang tersebut. Mendikbud menjelaskan, 75 persen sekolah di Indonesia tidak memenuhi standar layanan minimal pendidikan. Berdasarkan pemetaan Kemendikbud terhadap 40.000 sekolah pada 2012, diketahui bahwa isi, proses, fasilitas dan pengelolaan sebagian besar sekolah saat ini masih belum sesuai standar 
pendidikan yang baik seperti yang diamanatkan oleh undang-undang (Kompas.com, 2 Desember 2014).

Sekolah juga merupakan sebuah organisasi yang selain menjadi tempat untuk memberi pelajaran dan menerima pelajaran, juga terdapat sekelompok orang yang melakukan hubungan kerja sama yaitu, kepala sekolah, kelompok guru, kelompok tenaga administrasi, pustakawan, dan kelompok peserta didik. Adanya hubungan kerjasama yang baik dari sekelompok orang yang ada pada suatu sekolah dapat meningkatkan mutu dan kualitas pendidikan di sekolah tersebut. Sebagai contoh bagaimana peran kepemimpinan dan usaha seorang kepala sekolah untuk dapat meningkatkan kinerja guru-gurunya agar pendidikan di sekolah tersebut dapat berjalan dengan baik.

Berdasarkan paparan tersebut di atas, penelitian ini bermaksud mengungkap bagaimana dan apa saja peran kepemimpinan kepala sekolah dalam upaya untuk meningkatkan kinerja guru di MTs Patra Mandiri Plaju, Palembang. Madrasah ini dipilih sebagai objek penelitian karena: 1) berdasarkan data alumni sekolah peneliti, hampir sebagian alumni melanjutkan pendidikan ke MTS Patra M andiri, Plaju, 2) M Ts Patra M andiri Plaju sudah terakreditasi dengan predikat " $A$ ", 3.sudah banyak prestasi yang diraih oleh guru maupun siswa MTs Patra Mandiri, Plaju ini.

Penelitian ini dilakukan karena menurut hasil penelitian Wahyudi, Thomas dan Rediana (2012) mengungkapkan bahwa terdapat pengaruh simultan disiplin kerja, motivasi kerja, dan supervisi kepala sekolah terhadap kinerja guru sebesar 65,4\%. Terdapat pengaruh parsial disiplin kerja sebesar $17,56 \%$, motivasi kerja sebesar $27,7 \%$, dan suvervisi kepala sekolah sebesar 15,21\% terhadap kinerja guru. Dengan adanya disiplin kerja, motivasi kerja, dan suvervisi kepala sekolah dapat meningkatkan kinerja guru. Sedangkan hasil penelitian lain yang dilakukan oleh Sudharto (2012) mengungkapkan bahwa Kinerja kepala sekolah secara langsung maupun tidak langsung dipengaruhi oleh budaya organisasi sekolah, pengalaman kerja, kompensasi, kepuasan kerja, dan motivasi kerja baik secara serempak seluruh variabel independen maupun secara sendiri-sendiri per variabel independen. Besarnya pengaruh atau sumbangan efektif (SE) secara bersama-sama 81,6\%, sedangkan untuk masing-masing variabel, variabel budaya organisasi 9,2\%, pengalaman kerja 3,5\%, kompensasi 3,6\% kepuasan kerja $4,3 \%$, dan motivasi 4,2\%. Diantara kelima variabel tersebut, budaya organisasi sekolah pengaruhnya sangat dominan terhadap kinerja kepala sekolah jika dibandingkan dengan variabel lainnya yang diteliti. Urutan selanjutnya adalah kepuasan kerja, motivasi kerja, kompensasi, dan pengalaman kerja. 


\section{Kepemimpinan Kepala Sekolah}

Kepemimpinan telah dideskripsikan oleh beberapa pakar merupakan suatu tindakan yang memengaruhi orang lain atau bawahannya agar mau bekerja sama untuk mencapai tujuan-tujuan tertentu, Yulk mengartikan bahwa Kepemimpinan adalah proses mempengaruhi orang lain untuk memahami dan setuju dengan apa yang perlu dilakukan dan bagaimana tugas itu dilakukan secara efektif, serta proses memfasilitasi upaya individu dan kolektif untuk mencapai tujuan bersama (Edison, 2016:89).

Jadi, Kepemimpinan adalah Proses mempengaruhi orang lain dalam suatu organisasi untuk mencapai tujuan dan kepentingan bersama dari suatu organisasi tersebut. Artinya, keberhasilan ataupun kegagalan dalam mencapai tujuan organisasi banyak ditentukan oleh gaya kepemimpinan seseorang dalam mengelola sumber daya yang ada. Dan, dari gaya kepemimpinan inilah suasana lingkungan kerja ditentukan. Sedangkan, Kepala Sekolah adalah guru yang memenuhi persyaratan tertentu sehingga dapat diberi tugas tambahan memimpin suatu sekolah yakni sebagai Kepala Sekolah (Ahmad, 2016:13).

Lama masa jabatan seorang kepala sekolah dalam satu periode adalah empat tahun untuk mengendalikan sekolah tersebut. Untuk dapat diangkat menjadi kepala sekolah, seorang guru harus mempunyai persyaratan umum dan persyaratan khusus. Persyaratan umum adalah: a) beriman dan bertakwa kepada Tuhan Yang Maha Esa, b) usia setinggi-tingginya 56 tahun, c) sehat jasmani dan rohani, d) tidak pernah terkena hukuman disiplin sedang dan/atau berat sesuai ketentuan berlaku, e) aktif mengajar dan membimbing siswa minimal 5 (lima) tahun pada sekolah setingkat dan sejenis jenjang sekolah masing-masing. Persyaratan khusus terutama bagi calon Kepala Sekolah Dasar, harus berijasah minimal S1 PGSD yang memiliki jabatan Guru Muda Tingkat Satu. Dalam peraturan Menteri Pendidikan dan Kebudayaan RI Nomor 13 Tahun 2007 tanggal 17 April 2007 bahwa pengangkatan kepala sekolah harus memiliki kualifikasi umum. Kualifikasi Umum Kepala Sekolah/Madrasah adalah: a) memiliki kualifikasi akademik sarjana (S1) atau Diploma empat (D-IV) Kependidikan atau non kependidikan pada perguruan tinggi yang terakreditasi; b) pada waktu diangkat sebagai kepala sekolah berusia setinggi-tingginya 56 tahun; c) memiliki pengalaman mengajar sekurangkurangnya 5 tahun menurut jenjang sekolah masing-masing; d) memiliki pangkat serendahrendahnya III/C bagi pegawai negeri sipil (PNS) dan bagi non PNS disetarakan dengan kepangkatan yang dikeluarkan oleh Yayasan atau lembaga yang berwenang.

Di samping persyaratan umum tersebut di atas, juga harus memenuhi persyaratan yakni memilki kompetensi sebagai berikut: a) Berkepribadian, yakni berakhlak mulia, 
mengembangkan budaya dan tradisi akhlak mulia, dan menjadi teladan akhlak mulia bagi komunitas sekolah/madrasah. Memilki integritas kepribadian sebagai pemimpin. Memiliki keinginan yang kuat dalam pengembangan diri sebagai kepala sekolah/madrasah. Bersikap terbuka dalam melaksanakan tugas pokok dan fungsi. Mengendalikan diri dalam menghadapi masalah dalam pekerjaan sebagai kepala sekolah/madrasah. Memilki bakat dan minat jabatan sebagai pimpinan pendidikan; b) memilki manajerial, yakni menyusun perencanaan sekolah/madrasah untuk berbagai tingkatan perencanaan; c) memiliki jiwa kewirausahaan yakni menciptakan inovasi yang berguna bagi pengembangan sekolah/madrasah; d) melaksanakan supervisi, yakni merencanakan program supervisi akademik dalam rangka peningkatan profesionalisme guru; e) berjiwa sosial, harus bekerjasama dengan pihak lain untuk kepentingan sekolah/madrasah.

\section{Kinerja Guru}

Istilah kinerja merupakan terjemahan dari bahasa Inggris, dari kata perpormance. Kata perpormance berasal dari kata to perform yang berarti menampilkan atau melaksanakan. Perpormance berarti prestasi kerja, pencapaian kerja, penampilan kerja atau hasil kerja. Dalam Kamus Besar Bahasa Indonesia kinerja berarti sesuatu yang dicapai, prestasi yang diperlihatkan, atau kemampuan kerja. Kinerja merupakan hasil kerja yang dicapai oleh seseorang atau sekelompok orang dalam suatu organisasi, sesuai dengan wewenang dan tanggung jawab masing-masing, dalam rangka mencapai tujuan organisasi (Ardiansyah, 2011).

Menurut Mangkunegara (2011:67) Kinerja adalah hasil kerja secara kualitas dan kuantitas yang dicapai oleh seorang pegawai dalam melaksanakan tugasnya sesuai tanggung jawab yang diberikan kepadanya. Sementara itu menurut T. Aritonang kinerja adalah hasil kerja yang dapat dicapai oleh seseorang atau kelompok orang dalam organisasi, sesuai dengan wewenang dan tanggung jawab masing-masing dalam upaya mencapai tujuan organisasi bersangkutan secara legal, tidak melanggar hukum, dan sesuai dengan moral maupun etika (Barnawi \& Arifin 2012:12). Sedangkan menurut Rachmawati (2013:16) kinerja adalah tingkat keberhasilan seseorang atau kelompok orang dalam melaksanakan tugas dan tanggung jawabnya serta kemampuan untuk mencapai tujuan dan standar yang telah ditetapkan.

Berdasarkan pendapat di atas dapat disimpulkan bahwa kinerja adalah tingkat keberhasilan seseorang atau kelompok orang dalam melaksanakan tugas sesuai dengan tanggung jawab dan wewenangnya berdasarkan standar kinerja yang telah ditetapkan selama periode tertentu dalam rangka mencapai tujuan organisasi. Dalam kaitannya dengan profesi guru, kinerja guru dapat diartikan sebagai tingkat keberhasilan guru dalam melaksanakan 
tugas pendidikan sesuai dengan tanggung jawab dan wewenangnya berdasarkan standar kerja yang telah ditetapkan selama periode tertentu dalam rangka mencapai tujuan pendidikan. Standar kinerja guru berhubungan dengan kualitas guru dalam menjalankan tugasnya seperti: (1) bekerja dengan siswa secara individual, (2) persiapan dan perencanaan pembelajaran, (3) pendayagunaan media pembelajaran, (4) melibatkan siswa dalam berbagai pengalaman belajar, dan (5) kepemimpinan yang efektif dari guru.

Lebih lanjut kinerja guru oleh Yuliejantiningsih (2012:240) diartikan sebagai perwujudan kemampuan dan keterampilan berdasarkan kewenangan yang dimilki dalam tugas pokoknya, yaitu keterampilan mengajar. Perwujudan kemampuan tersebut adalah kegiatan guru dalam proses pembelajaran yaitu merencanakan pembelajaran, melaksanakan kegiatan pembelajaran, dan menilai hasil belajar.

Dalam kegiatannya, kinerja guru dipengaruhi oleh beberapa faktor. Menurut Mangkunegara (2011:67) faktor yang mempengaruhi kinerja guru ada dua yaitu faktor kemampuan (ability) dan faktor motivasi (motivision). Secara psikologis, kemampuan guru terdiri dari kemampuan pengetahuan dan kemampuan keterampilan. Artinya seorang guru yang memilki latar belakang pendidikan yang tinggi dan sesuai bidangnya serta terampil dalam mengerjakan pekerjaan sehari-hari, maka ia akan lebih mudah mencapai kinerja yang diharapkan. Oleh karena itu, seorang guru semaksimal mungkin diupayakan mengajar sesuai bidangnya sehingga dapat diperoleh hasil pembelajaran yang efektif dan bermutu.

Senada dengan pendapat di atas, Malthis dan Jackson, menambahkan ada tiga faktor yang mempengaruhi kinerja karyawan termasuk guru yaitu (1) kemampuan, (2) usaha yang dicurahkan, dan (3) dukungan organisasi. Faktor kemampuan berkaitan dengan bakat dan minat yang dimiliki seseorang (Ardiansyah, 2011:34). Berbeda dengan pendapat Malthis dan Jackson, faktor-faktor yang mempengaruhi kinerja guru menurut Barnawi \& Arifin (2012:43) dapat dikelompokkan menjadi dua yaitu faktor internal dan eksternal. Faktor internal kinerja guru adalah faktor yang datang dari dalam diri guru yang dapat mempengaruhi kinerjanya, seperti kemampuan, keterampilan, kepribadian, persepsi, motivasi menjadi guru, pengalaman lapangan dan latar belakang keluarga. Sedangkan faktor eksternal kinerja guru adalah faktor yang datang dari luar guru yang dapat mempengaruhi kinerjanya, seperti gaji, sarana dan prasarana, lingkungan kerja fisik, dan kepemimpinan.

Jadi berdasarkan pendapat di atas dapat disimpulkan bahwa faktor-faktor yang mempengaruhi kinerja guru dapat berasal dari dalam seperti kemampuan, motivasi, 
keterampilan, kedisiplinan dan pendidikan. Ada juga faktor dari luar seperti iklim kerja, budaya organisasi, kepemimpinan, jaminan sosial dan tingkat penghasilan.

\section{Metode Penelitian}

Dalam penelitian ini peneliti berusaha mengungkap bagaimana peran kepemimpinan kepala sekolah dalam upaya untuk meningkatkan kinerja guru di MTs Patra Mandiri Plaju, Palembang. Data dalam penelitian ini adalah beberapa hal yang dilakukan oleh kepala sekolah dalam upaya meningkatkan kinerja guru-gurunya sehubungan dengan peran kepemimpinannya sebagai kepala sekolah. Objek dalam penelitian ini adalah Kepala sekolah dan guru-guru pada MTs Patra Mandiri Plaju, Palembang, teori tentang kepemimpinan dan kinerja guru. Peneliti melakukan wawancara langsung ke kepala sekolah dan guru-guru MTs Patra Mandiri Plaju, Palembang. M etode pengumpulan data yang digunakan dalam penelitan ini adalah wawancara dan observasi. Menurut Sutrisno (2004), sebagai metode ilmiah, observasi biasanya diartikan sebagai pengamatan dan pencatatan dengan sistematis atas fenomena-fenomena yang diteliti. Selain dengan wawancara peneliti juga memperoleh data dengan mengumpulkan informasi berupa dokumen data-data tentang guru-guru MTs Patra Mandiri Plaju, mulai dari jumlah guru, kualifikasi pendidikan, data pribadi serta beberapa catatan prestasi kepala sekolah dan guru-guru.

\section{Hasil Penelitian dan Pembahasan}

Beberapa usaha yang dilakukan Kepala Sekolah di tingkat Madrasah Patra M andiri, Plaju menjadi alternatif untuk meningkatkan kinerja guru-guru dalam profesionalisme kerjanya. Usaha tersebut dilakukan dalam rangka mendorong peningkatan prestasi dan peningkatan kualitas kinerja guru-guru dalam melaksanakan kegiatan pembelajaran bagi para siswa di madrasah tersebut (Hasil wawancara dengan Abdul Kadir/Kepala MTs Patra Mandiri Plaju Palembang, 9 November 2016)

Menurut Locke, kepala sekolah harus mendorong terwujudnya visi, misi, tujuan, dan sasaran melalui program-program yang terencana dan bertahap. Di samping memilki pengetahuan, keterampilan, serta kemampuan, juga harus memilki motif dan bakat yang merupakan karakteristik dari seorang pemimpin yang efektif (Ahmad, 2016: 9).

Jumlah guru di MTs Patra M andiri Plaju sebanyak 44 orang dengan rincian 16 guru lakilaki dan 28 orang guru perempuan. Ditambah dengan 8 orang staf yang terdiri dari tenaga Tata Usaha (TU), Pustakawati, Office Boy (OB), Satpam, Tukang Kebun dan Penjaga Seekolah. Latar belakang Pendidikan para guru berbeda-beda. Mulai dari lulusan Universitas negeri maupun 
swasta, seperti Universitas Sriwijaya (UNSRI), IAIN Raden Fattah Palembang, dan yang paling banyak adalah lulusan dari FKIP Universitas PGRI Palembang. Sedangkan jumlah siswa di MTs Patra M andiri pada tahun pembelajaran 2016-2017 adalah sebanyak 476 siswa, terdiri dari 207 siswa laki-laki dan 269 siswa perempuan. Yang ke semua siswa ini terbagi dalam beberapa rombel yakni: kelas VII dan VII masing-masing sebanyak 4 rombel dan kelas IX sebanyak 5 rombel.

Berdasarakan hasil wawancara peneliti dengan Kepala Sekolah MTs Patra Mandiri Plaju dan beberapa orang guru tentang kinerja guru di sekolah tersebut, diperoleh keterangan bahwa adapun peran kepemimpinan kepala sekolah dalam upaya untuk meningkatkan kinerja guru-gurunya, selain dengan pemberian gaji bulanan, adalah juga dengan pemberian beberapa reward dan beberapa insentif di luar gaji dan anggaran MTs tersebut. Beberapa insentif tersebut antara lain: 1) diberikan tambahan penghasilan sebesar Rp.200.000/bulan bagi guruguru yang telah mengabdi minimal 1 tahun masa kerja, mengajar 18 jam lebih dan kehadiran mengajar di sekolah 100\%, yang jumlah tambahan penghasilan ini setiap tahunnya berubahubah dan cenderung meningkat, 2) Pemberian seragam kerja setiap tahunnya bagi para guruguru dan semua staf, 3) setiap ramadhan dan menjelang hari raya idul fitri guru diberikan THR dan paket lebaran, 4) setiap akhir tahun pembelajaran guru-guru diajak berwisata tetap dengan syarat telah mengabdi masa kerja minimal 1 tahun dan tidak pernah alpa melaksanakan tugasnya, 5) setiap tahun juga, sarana dan prasarana sekolah yang berkaitan dengan lingkungan kerja dan pembelajaran di dalam kelas terus ditambah dan ditingkatkan, sehingga guru merasa betah dan nyaman berada di sekolah baik ketika guru berada di lingkungan sekitar sekolah maupun saat pembelajaran di kelas.

Selain beberapa hal yang telah disebutkan di atas, peran kepala sekolah di M Ts Patra Mandiri Plaju ini untuk meningkatkan kinerja guru-gurunya dalam hal kinerja yang berkaitan dengan pembelajaran adalah dengan mengadakan supervisi profesional kinerja dan administrasi kelas kepada setiap guru. Dalam hal supervisi ini, kepala sekolah bekerjasama dengan Penilik/Pengawas sekolah. Dan agar memudahkan kepala sekolah untuk memantau kinerja guru, di setiap kelas telah dipasang CCTV yang bisa dipantau secara langsung dan menyeluruh oleh kepala sekolah, sehingga para guru benar-benar bekerja secara profesional dan malu jika berbuat kesalahan yang sifatnya menghambat proses pembelajaran siswa di kelas.

Dengan adanya beberapa insentif dan supervisi profesional kinerja dan administrasi kelas, ditambahkan kepala M Ts lagi, memang dirasakan adanya peningkatan kinerja guru-guru 
setiap tahunnya. Peningkatan kinerja ini dapat terlihat dari beberapa prestasi yang dicapai guru-guru setiap tahunnya. Diantaranya, Kepala MTs Patra Mandiri Plaju, Drs. Abdul Kadir, pada tahun 2016 diberi penghargaan oleh Bapak Walikota Palembang, Ir.Harnojoyo untuk berangkat Haji gratis. Dan guru Olahraga ditunjuk oleh Disdikpora Palembang sebagai Pelatih Drumb Band tingkat provinsi yang di setiap even pertandingan selalu menjadi juri. Beberapa guru yang lain ada yang pernah menjadi guru teladan tingkat kecamatan.

\section{Kesimpulan}

Peran Kepemimpinan Kepala MTs Patra Mandiri Plaju dalam upaya meningkatkan kinerja guru-gurunya adalah selain dengan pemberian gaji rutin setiap bulan, juga diberikan beberapa insentif dan tambahan penghasilan di luar gaji. Selain pemberian beberapa insentif dan tambahan penghasilan, kepala sekolah juga bekerjasama dengan Pengawas/Penilik sekolah melakukan supervisi profesional kinerja guru dan supervisi administrasi pembelajaran di kelas. Setiap kelas telah dipasang CCTV sehingga kinerja guru di kelas dapat dipantau secara langsung oleh kepala sekolah. Peningkatan kinerja guru di MTs Patra Mandiri Plaju ini juga terlihat dari beberapa catatan prestasi yang diraih oleh para guru termasuk juga oleh kepala sekolah.

\section{Daftar Pustaka}

Ahmad, Syarwani. (2016). Ketahanmalangan Kepemimpinan Kepala Sekolah: Salah Satu Faktor Penentu Keberhasilan Kepala Sekolah. Yogyakarta: Deepublish

Ardiansyah, M (2011). "Kinerja Guru” (online), http://kabarpendidikan.blogspot.com/2011/04, (diakses 6 November 2016)

Arifin, N.2010."Analisis Budaya Organisasional Terhadap Komitmen Kerja Karyawan Dalam Peningkatan Kinerja Organisasional Karyawan Pada Koperasi BMT di Kecamatan Jepara". Jurnal Ekonomi dan Pendidikan STIENU Jepara, Volume 8, Nomor 2, November 2010

Edison, Emron dkk. (2016). Manajemen Sumber Daya Manusia: Strategi dan Perubahan dalam Rangka Meningkatkan Kinerja Pegawai dan Organisasi. Bandung: Alfabeta

Kompas.com. (2014). Berita Buruk Pendidikan Indonesia. Diakses tanggal 16 November 2016 darihttp://edukasi.kompas.com/read/2014/12/02/18365971/Berita.Buruk.Pendidikan.In donesia

Sutrisno, Hadi. (2004). Metodologi Research Jilid 2. Yogyakarta: Andi Publisher UndangUndang Nomor 20 Tahun 2003 Pasal 3 